\title{
The ocular pathway, a risk for developing COVID-19
}

\section{La ruta ocular, un riesgo para desarrollar COVID-19}

\author{
María L. Ruiz-Morales*
}

Hospital General de Zona 32, Instituto Mexicano del Seguro Social; Subdivision of Family Medicine, Faculty of Medicine, Universidad Nacional Autónoma de México. Mexico City, Mexico

Dear Editor,

To date, SARS-CoV-2 has caused more than $71,298,626$ infections and more than 1,599,608 deaths worldwide ${ }^{1}$.

With reference to previous studies, the virus is known to spread rapidly from person to person by droplet transmission, fomites, contact, and possibly aerosols ${ }^{2}$.

The ocular route has been described as a secondary route of transmission and spread of the virus, due to the extension of the ocular tissues, the contact surface, the receptors and the pathophysiology. The eyes should be considered as a possible pathway for viral spread towards the nasopharynx and then to the respiratory tract $^{2}$. Likewise, ocular involvement in COVID-19 has been described as a prognostic factor for the risk of developing severe lung disease.

It is evident, then, that the spread of SARS-CoV-2 must be contained by both routes, the respiratory and the ocular? ${ }^{2}$.

The World Health Organization (WHO), in response to the international consensus of experts, has recommended infection prevention and control strategies, among which stand out a minimum physical distance of 1 meter, precautions when coughing and sneezing, frequent hand washing, use of non-medical grade (reusable cloth) masks for the community, and medical-grade masks (respiratory or self-filtering: FFP2, FFP3, N95 or N99) for sick people and healthcare workers ${ }^{2-4}$.
Plastic face shields for eye protection and additional protection of the nose and mouth are recommended, until now, only for health personnel in areas that treat patients with COVID-19?

The objective of this letter is to exhort the general population outside of hospital settings and health personnel in non-COVID-19 institutions to wear masks together with a plastic shield (face shield) to protect the respiratory and ocular routes from the transmission of SARS-CoV-2.

This recommendation is supported by laboratory simulation tests, which have shown that the use of non-medical (reusable cloth) masks is not efficient in preventing the transmission of SARS-CoV-2 at distances less than 1 meter, as well as that wearing plastic face shields as the only means of protection does not prevent the transmission of the virus.

Given the evidence of the increase in the number of cases around the world, and until the majority of people around the world have been vaccinated against SARS-CoV-2, it is necessary to seek new protection alternatives.

In response, the WHO has called on the world community to prevent contagion: Do it all! 5 .

The use of cloth face masks in the general population and medical-grade masks in health personnel, as well as a face shield, can add to the effort. Let's do everything to prevent more infected people and more deaths. We must not give up, adds the $\mathrm{WHO}^{6}$. 


\section{References}

1. Channel News Asia. Novel Coronavirus Map. 2020. Disponible en: https:// infographics.channelnewsasia.com/covid-19/map.html.

2. Chu DK, Akl EA, Duda S, Solo K, Yaacoub S, Schünemann HJ; COVID-19 Systematic Urgent Review Group Effort (SURGE). Physical distancing, face masks, and eye protection to prevent person-to-person transmission of SARS-CoV-2 and COVID-19: a systematic review and meta-analysis. Lancet. 2020;395:1973-87.

3. Organización Mundial de la Salud. Cronología de la respuesta de la OMS a la COVID-19. 29 de junio de 2020 Declaración. Última actualización: 9 de septiembre de 2020. Disponible en: https://www.who.int/es/news/ item/29-06-2020-covidtimeline.
4. Organización Mundial de la Salud. Recomendaciones sobre el uso de mascarillas en el contexto de la COVID-19. Orientaciones provisionales 5 de junio de 2020. Disponible en: https://apps.who.int/iris/bitstream/ handle/10665/332657/WHO-2019-nCov-IPC_Masks-2020.4-spa.pdf.

5. World Health Organization. Director-General's opening remarks at the media briefing on COVID-19, 3 August 2020. Disponible en: https://www.who.int/director-general/speeches/detail/who-director-general-s-opening-remarks-at-the-media-briefing-on-covid-19---3-august-2020. 6. World Health Organization. Director-General's opening remarks at the media briefing on COVID-19, 26 October 2020. Disponible en: https://www.who.int/director-general/speeches/detail/who-director-general-s-opening-remarks-at-the-media-briefing-on-covid-19---26-october-2020. 